\title{
Acute and sublethal intoxication of malathion in an Indian major carp, Labeo rohita: haematological and biochemical responses.
}

\author{
Juginu Mankuzhiyil Sivanandan ${ }^{1, *(\mathbb{D}), \text { Binukumari }^{1}}$ \\ ${ }^{1}$ Department of Zoology, Kongunadu Arts and Science College, Coimbatore, Tamilnadu, India-641029 \\ *Correspondence: juginums@gmail.com
}

Received: September 3, 2020 Accepted: July 9, 2021

\begin{abstract}
This study aimed to determine the median lethal concentration (96-h LC50), acute and sublethal effects of malathion, an organophosphorus pesticide on hematological and biochemical responses in an Indian major carp, Labeo rohita. In this study, the LC 50 value of malathion for $96 \mathrm{~h}$ was found to be $3.4 \mathrm{ppm}$. During acute (3.4 ppm) and sublethal [1/10th of 96 h LC50 value $(0.34 \mathrm{ppm})$ studies, all the hematological parameters except WBC were significantly decreased $(\mathrm{p}<0.05)$. Besides, when compared with the control group, a significant $(\mathrm{p}<0.05)$ decrease in biochemical activity was also observed in malathion treated fish during acute and sublethal exposure periods. These results suggest that the tested concentrations of malathion could have significant adverse effects on the hematological and biochemical parameters of fish, Labeo rohita. The changes in the parameters can be effectively used to determine the impact of malathion in the aquatic ecosystem.
\end{abstract}

Keywords: Malathion, Labeo rohita, Haematology, Biochemical, Acute study, Sublethal toxicity

\section{Introduction}

The possibility of being contaminated by a variety of chemicals in aquatic ecosystems that run through agricultural areas is high [1]. Water is one of the primary ways pesticides are transported from an application area to other locations in the environment. Upon entering the aquatic environment produce multiple changes in the organism by altering the growth rate, nutritional value, behavioral pattern and so on. It is exigent to find out the detrimental effects of pollutants especially pesticides on fish since they form an important link in the food chain and their contamination by pesticides imbalance the aquatic system. Fishes are an important source of protein and form a part of human food [2]. In India, nontarget organisms are believed to be affected by the chemical formulations employed in agricultural practices and to find their way to freshwater bodies, ultimately polluting them [3]. To monitor the physiological and pathological changes in fishes, knowledge of hematological characters is an important tool [4]. Alterations of blood components are important biomonitoring tools in toxicological research because of the potentiality for rapid assessment of the chronic toxicities of a compound [41]. Generally, any unfavorable changes in water quality are reflected in the blood of the aquatic organisms by separating the blood cells with thin epithelial membrane [42]. Exogenous factors such as stress always induce major changes in blood composition [5]. For example, fluctuations in the levels of red blood cells (RBC), white blood cells (RBC), hemoglobin $(\mathrm{Hb})$ concentration, and other basic components occurred in response to ecological and physiological conditions [6].

Likewise, exposure to pesticides causes severe alterations in the tissue biochemistry of fishes [7]. The biochemical alterations in organisms are considered as most sensitive and earliest events of any pollutant damage [43]. The most toxicants exert their effects at basic level of the organism by reacting with enzymes or metabolites and other functional components of the cell [44]. The measurement of biochemical changes in the tissue of fish under exposure to toxicants may be used to predict the toxic effect of pollutants. The pesticide, malathion (S-1,2-bis (ethoxycarbonyl) ethyl O, O-dimethyl phosphorodithioate) is a commonly used organophosphorus pesticide which once introduced into the environment, it may cause serious intimidation to aquatic organisms and cause severe metabolic disturbances in non-target species like fish and freshwater mussels [8].

Therefore, in the present investigation, an attempt has been made to study the effect of malathion on alterations in hematological and biochemical parameters of Labeo rohita with particular reference to the concentration of the pesticide and exposure duration. 


\section{Materials and Methods Test pesticide}

Technical grade malathion (CAS 121-75-5; 95\%) manufactured by Kalyani Industries Ltd., Mumbai, India was taken for evaluation of its toxicity.

\section{Fish and culture condition}

Considering the limitations of the laboratory facilities, a static bioassay method was adopted [9]. Fingerlings of L.rohita $(12 \pm 0.24 \mathrm{~g}$ in body weight and $6.4 \pm 0.02 \mathrm{~cm}$ in body length) were collected from Tamil Nadu Fisheries Development Corporation Limited, Aliyar Fish Farm, Tamil Nadu, India. Under natural photoperiod conditions (12:12h light to the dark regime) before the experimentation, the fishes were acclimated to the laboratory condition for a month in 350-L fiberglass tanks containing aerated and dechlorinated water. The fishes were fed once in a day with rice bran and groundnut oil cake (ad libitum) during acclimatization and exposure periods. Each day, $80 \%$ of the water volume was renewed to assure water quality, and dead fishes (if occurred) were removed. The physicochemical characteristics of the test water were temperature $\left(25.0 \pm 1.0^{\circ} \mathrm{C}\right), \mathrm{pH}(7.0 \pm 1)$, salinity $(0.5 \pm 0.02 \mathrm{ppt})$, and total hardness $\left(16.1 \pm 0.5 \mathrm{mg} \mathrm{L}^{-1}\right)$ [9]. To avoid prandial effects during the assay, the fishes were starved for $24 \mathrm{~h}$ before experimentation.

\section{Determination of $\mathrm{LC}_{50}$ for $96 \mathrm{~h}$}

Preliminary toxicity tests were carried out to find out the median lethal tolerance limit of fish to malathion for 96 h. For obtaining LC 50 concentration, eight circular plastic tubs of $20 \mathrm{~L}$ capacity were used. 10 fishes were introduced in each tub with $20 \mathrm{~L}$ of water in each which was already received with different concentrations of malathion $(1.4,2.4,3.4,4.4,5.4$, 6.4, 7.4, and $8.4 \mathrm{ppm}$ ) for $96 \mathrm{~h}$ treatment. 20 fishes each in tubs with $20 \mathrm{~L}$ of water were also kept simultaneously as control. The mortality/ survival of fish in the experimental tubs was recorded after $96 \mathrm{~h}$. The concentration at which $50 \%$ kill of fish occurred after $96 \mathrm{~h}$ treatment was taken as the median lethal concentration (LC50) for $96 \mathrm{~h}$. Five such preliminary toxicity tests were conducted for arriving at the median lethal concentration. LC 50 for $96 \mathrm{~h}$ was calculated by probity analysis method [10].

\section{Acute toxicity study for $96 \mathrm{~h}$}

For the determination of malathion toxicity study, five circular plastic tubs with $50 \mathrm{~L}$ capacity were taken and each was filled with $35 \mathrm{~L}$ of dechlorinated tap water. Then, $\mathrm{LC}_{50} 96 \mathrm{~h}$ concentration of malathion (3.4 ppm) was added to all tubs and mixed well. From the stock, 20 healthy fishes starved for $48 \mathrm{~h}$ were introduced into each tub. Parallel control of 40 fishes in different circular tubs was also maintained under similar conditions. At the end of $96 \mathrm{~h}$, fish from the control and treated groups were taken for further analyses.

\section{Sublethal toxicity study for $\mathbf{3 0}$ days}

The sublethal toxicity experiment was carried out simultaneously with acute studies. For the study, five wellcleaned glass aquaria of $130 \mathrm{~L}$ capacity were taken and filled with $100 \mathrm{~L}$ of water and 50 fishes which were randomly selected from the stock was transferred into the aquaria. Then 1/10th of the $96 \mathrm{~h} \mathrm{LC} 50$ concentration of malathion $(0.34 \mathrm{ppm})$ was taken) and added to each aquarium [11]. The same control fish groups used in acute toxicity studies were also maintained for this study. Water was changed daily to avoid the accumulation of fecal matter and was renewed with the toxicant. The study was conducted for 30 days. 20 fishes were randomly selected from control and malathion treated glass aquarium and sacrificed without anesthetizing for further analysis upon completion of the stipulated exposure period of 30 days.

\section{Hematology}

At the end of $96 \mathrm{~h}$ and $30 \mathrm{~d}$ period exposure, blood was drawn from control and malathion treated fishes by cardiac puncture using a hypodermic syringe previously rinsed with heparin, an anticoagulant. Pooled blood was transferred into small vials, which is previously rinsed with heparin. The whole blood was used for the estimation of erythrocyte, leukocyte counts, hemoglobin, mean corpuscular volume (MCV), and mean corpuscular hemoglobin (MCH). Erythrocyte and leucocytes were counted by using a hemocytometer [12]. The hemoglobin content of the blood was estimated by the cyanmethaemoglobin method [13]. Mean corpuscular volume (MCV) and mean corpuscular hemoglobin $(\mathrm{MCH})$ were calculated from the average values of $\mathrm{Hb} \%$ [14].

\section{Biochemical study: protein, carbohydrate, and lipid Estimation of total proteins}

Total protein content was estimated by the method Lowry et al [15]. $100 \mathrm{mg}$ of tissue was homogenized in $5 \mathrm{~mL}$ of cold distilled water. $5 \mathrm{~mL}$ of $0 \%$ TCA was immediately added to precipitate the protein. The precipitate was collected by 
centrifugation at $3000 \mathrm{rpm}$ for 15 minutes. The supernatant was discarded. The pellet was repeatedly washed with distilled water to remove the traces of TCA precipitated. Protein was re-dissolved in $0.1 \mathrm{~N} \mathrm{NaOH} .0 .5 \mathrm{~mL}$ of the solution was transferred into a test tube and $4 \mathrm{~mL}$ of alkaline copper sulphate $\left(50 \mathrm{~mL}\right.$ of $2 \% \mathrm{Na}_{2} \mathrm{CO}_{3}$ and $\mathrm{mL}, 0.5 \% \mathrm{CuSO}_{4} .5 \mathrm{H}_{2} \mathrm{O}$ in $1 \%$ sodium potassium tartrate) reagent was added followed by $0.4 \mathrm{~mL}$ of diluted commercial Folin's reagent (diluted with distilled water in 1:1 ratio). The optical density of blue color developed was read at $750 \mathrm{~nm}$ after 30 minutes on the addition of the reagent using a spectrophotometer. Bovine serum albumin was used as a standard.

\section{Estimation of carbohydrate}

The gill, liver, kidney, and muscle glycogen were estimated using the anthrone reagent method [16]. The sample was homogenized by adding $0.5 \mathrm{~mL}$ of $60 \% \mathrm{KOH}$ and $1 \mathrm{~mL}$ of $30 \% \mathrm{KOH}$, both prepared in water. The mixture was incubated in a boiling water bath for 30 minutes. $4 \mathrm{~mL}$ of ethanol was added to the homogenate, and it was kept in a refrigerator for 24 hours and then centrifuged at $3000 \mathrm{rpm}$ for 20 minutes. The pellet was resuspended in $1 \mathrm{~mL}$ of distilled water where 0.25 $\mathrm{mL}$ was taken and mixed with $1.75 \mathrm{~mL}$ of anthrone reagent and kept in a boiling water bath for 15 minutes. The color developed was read at $620 \mathrm{~nm}$ spectrophotometrically.

\section{Estimation of lipid}

Total lipids were estimated by using sulpho phospho vanillin method [17]. The dry tissue powder of the fish fry sample was homogenized with chloroform: methanol (2:1) and centrifuged at 2500rpm for 15minutes. A known amount of the supernatant was taken in a test tube and the solvent was removed under vacuum. To the residue, $0.5 \mathrm{~mL}$ of concentrated sulphuric acid was added and was kept in a boiling water bath for 15 minutes. After cooling to room temperature, $2.5 \mathrm{~mL}$ of the phosphoric acid vanillin reagent was added; thoroughly vortexed and the tubes were closed with cotton wool. Then they were incubated for 30 minutes at room temperature. The optical density was measured at $520 \mathrm{~nm}$ in a Spectrophotometer (Chemito-2000). The values were calculated against cholesterol standard and were presented as $\mathrm{mg} / \mathrm{g}$ dry weight of tissue powder.

\section{Statistical analysis}

The statistical analysis was made between control and malathion treated groups and the mean value of five individual observations was taken for each parameter. The standard error for the sample mean was calculated and the significance of sample means between control and malathion treated fishes were tested by using the student's t-test.

\section{Results}

To evaluate the potential toxicological effects of chemicals on aquatic organisms and to monitor water quality, aquatic toxicological tests are commonly used [18]. During the experiment, fishes showed marked behavioral changes such as erratic jumping movement, loss of movement coordination, hyperactivity, and increased gill mucous secretion [19,20].

\section{Hematological and biochemical changes during acute and sublethal exposure periods}

The changes in hematological and biochemical parameters of the fish Labeo rohita exposed to acute toxicity of malathion are presented in (Tables 1 and Table 2). During acute (3.4 ppm) treatment red blood corpuscle (RBC), hemoglobin, $\mathrm{MCV}, \mathrm{MCH}$, protein, carbohydrate, and lipid levels decreased whereas White blood corpuscle (WBC) increased in the pesticide-treated fishes. The graphical representations of the changes in the acute study are presented in (Figures 1-4).

Table 1. Changes in the hematological parameters ( $\mathrm{RBC}, \mathrm{Hb}, \mathrm{WBC}, \mathrm{MCV}, \mathrm{MCH})$ activity in Indian major carp, Labeo rohita treated with acute concentration of malathion $(3.4 \mathrm{ppm}, 96 \mathrm{~h})$.

\begin{tabular}{ccc}
\hline Hematological parameters & Control & Malathion treated fish \\
\hline $\mathrm{RBC}$ & $2.16 \pm 0.58$ & $1.52 \pm 0.21^{\star}(-29.63)$ \\
$\mathrm{Hb}$ & $2.79 \pm 0.68$ & $1.74 \pm 0.45^{\star}(-37.63)$ \\
$\mathrm{WBC}$ & $1.47 \pm 0.18$ & $2.18 \pm 0.62^{\star}(+48.3)$ \\
$\mathrm{MCV}$ & $31.38 \pm 1.27$ & $21.41 \pm 1.12^{\star}(-31.77)$ \\
$\mathrm{MCH}$ & $7.12 \pm 1.09$ & $5.21 \pm 1.03^{\star}(-26.83)$ \\
\hline
\end{tabular}

\footnotetext{
${ }^{1}$ Values are means \pm SE of five individual observations; (-) denotes percent decrease \& $(+)$ denotes percent increase over control in the parenthesis.

$2 *$ Values are significant at $\mathrm{p}<0.05$
} 
Table 2. Changes in the biochemical parameters (protein, carbohydrate, lipid) activity in Indian major carp, Labeo rohita treated with acute concentration of malathion $(3.4 \mathrm{ppm}, 96 \mathrm{~h})$.

\begin{tabular}{ccc}
\hline $\begin{array}{c}\text { Biochemical parameters } \\
(\mathbf{m g} / \mathbf{g} \text { wet tissue) }\end{array}$ & Control & Malathion treated fish \\
\hline Protein & & \\
Gill & $2.64 \pm 0.30$ & $1.42 \pm 0.10^{\star}(-46.21)$ \\
Liver & $3.23 \pm 0.08$ & $1.62 \pm 0.13^{\star}(-49.85)$ \\
Kidney & $2.14 \pm 0.15$ & $1.31 \pm 0.13^{\star}(-38.79)$ \\
Muscle & $1.34 \pm 0.10$ & $0.82 \pm 0.05^{\star}(-11.97)$ \\
Carbohydrate & & $11.60 \pm 0.13{ }^{\star}(-44.23)$ \\
Gill & & $8.12 \pm 0.19^{\star}(-54.25)$ \\
Liver & $20.8 \pm 0.13$ & $11.81 \pm 0.19^{\star}(-37.84)$ \\
Kidney & $17.75 \pm 0.18$ & $3.41 \pm 0.25^{\star}(-59.4)$ \\
Muscle & $19.0 \pm 0.12$ & $11.24 \pm 0.14{ }^{\star}(-58.98)$ \\
Lipid & $8.40 \pm 0.09$ & $13.4 \pm 0.15^{\star}(-40.71)$ \\
Gill & & $11.1 \pm 0.144^{\star}(-64.42)$ \\
Liver & & $9.3 \pm 0.11^{\star}(-66.9)$ \\
Kidney & $27.4 \pm 0.09$ & \\
Muscle & $22.6 \pm 0.08$ & \\
\hline
\end{tabular}

${ }^{1}$ Values are means \pm SE of five individual observations; (-) denotes percent decrease \& (+) denotes percent increase over control in the parenthesis. 2 *Values are significant at $\mathrm{p}<0.05$.

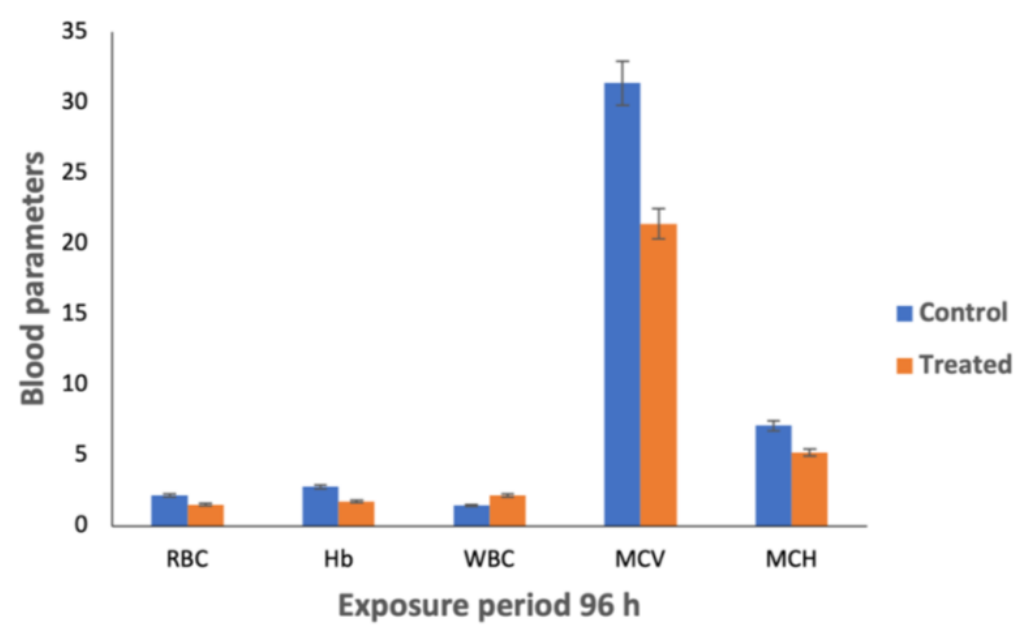

Figure 1. Hematological changes in gill, liver, kidney, and muscle of control and malathion treated fish (3.4 ppm; $96 \mathrm{~h})$. The bar represents SE of the mean. Comparison of means (control and treated fish) was done by student's t-test. 


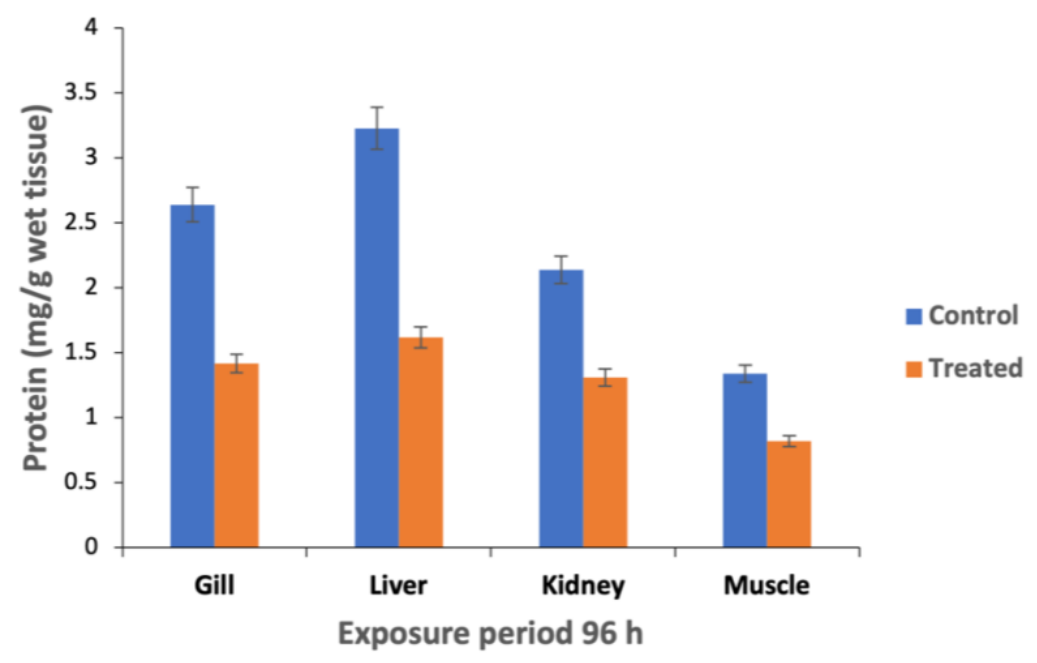

Figure 2. Changes in Protein metabolism of control and malathion treated fish (3.4 ppm; $96 \mathrm{~h})$. The bar represents SE of the mean. Comparison of means (control and treated fish) was done by Student's t-test.

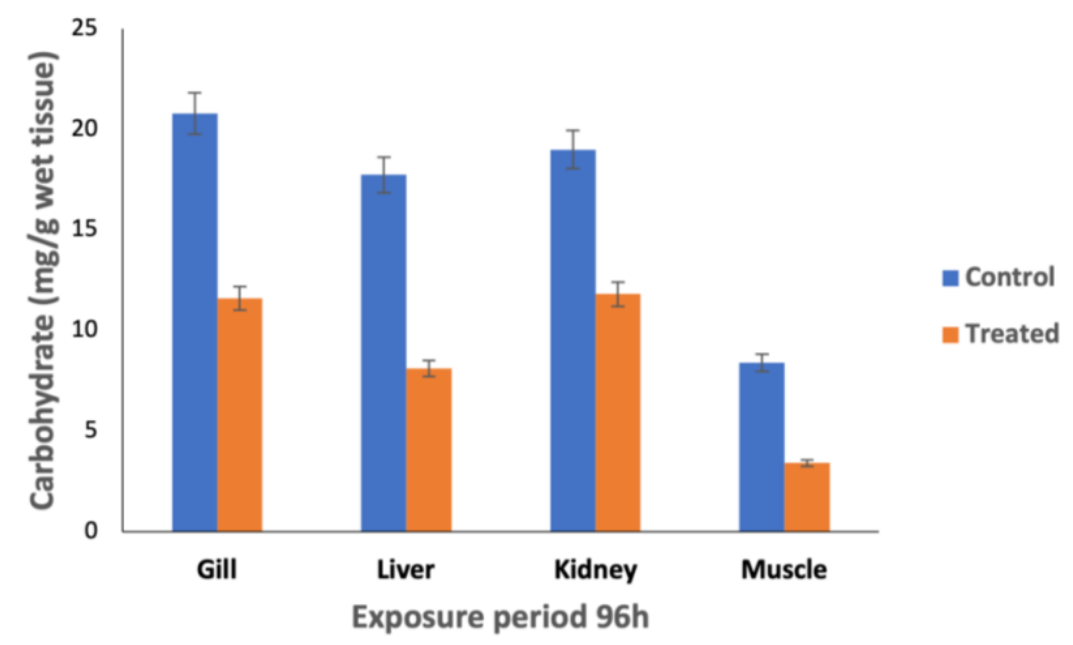

Figure 3. Changes in Carbohydrate metabolism of control and malathion treated fish (3.4 ppm; $96 \mathrm{~h})$. The bar represents SE of the mean. Comparison of means (control and treated fish) was done by Student's t-test.

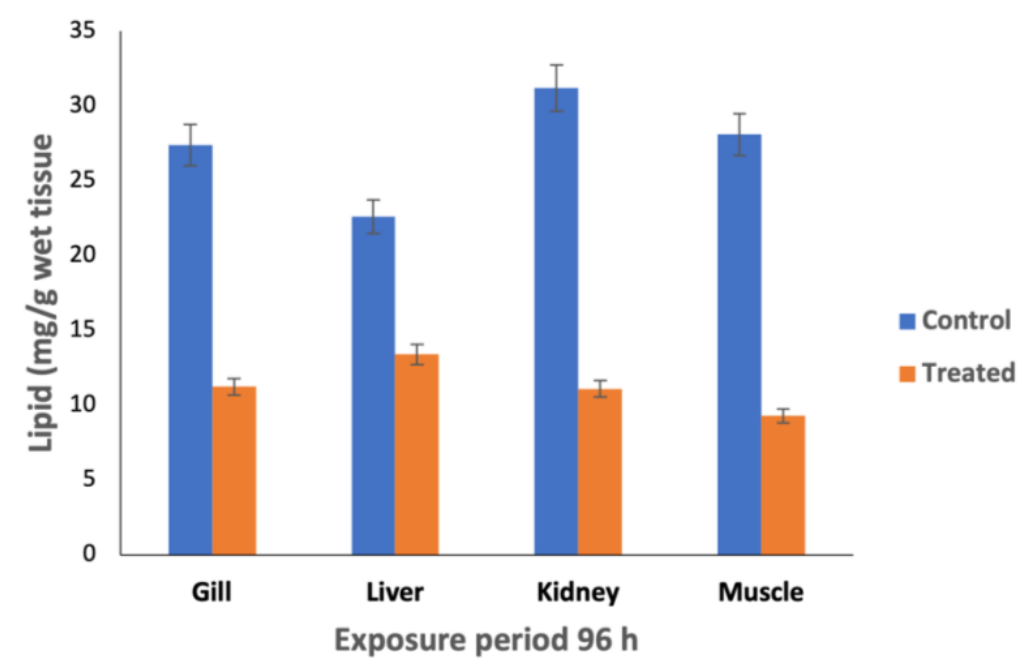

Figure 4. Changes in Lipid metabolism of control and malathion treated fish (3.4 ppm; $96 \mathrm{~h})$. The bar represents SE of the mean. Comparison of means (control and treated fish) was done by Student's t-test. 
Similarly, during the sublethal study using the concentration of $0.34 \mathrm{ppm}$ malathion, all the parameters showed the same trend of changes as in the acute study which is presented in (Table 3 and Table 4). Here also WBC showed a remarkable increase than other parameters in the study. (Figure 5-8) denote graphical representations of the changes in the sublethal study.

Table 3. Changes in the hematological parameters ( $\mathrm{RBC}, \mathrm{Hb}, \mathrm{WBC}, \mathrm{MCV}, \mathrm{MCH})$ activity in Indian major carp, Labeo rohita treated with sublethal concentration of malathion $(0.34 \mathrm{ppm}, 30$ days).

\begin{tabular}{ccc}
\hline Haematological parameters & Control & Malathion treated fish \\
\hline $\mathrm{RBC}$ & $2.16 \pm 0.58$ & $1.01 \pm 0.25^{\star}(-53.24)$ \\
$\mathrm{Hb}$ & $2.79 \pm 0.68$ & $1.25 \pm 0.39^{\star}(-55.2)$ \\
$\mathrm{WBC}$ & $1.47 \pm 0.18$ & $2.82 \pm 0.71^{\star}(+91.84)$ \\
$\mathrm{MCV}$ & $31.38 \pm 1.27$ & $18.40 \pm 1.19^{\star}(-41.36)$ \\
$\mathrm{MCH}$ & $7.12 \pm 1.09$ & $2.23 \pm 1.02^{\star}(-68.68)$
\end{tabular}

${ }^{1}$ Values are means \pm SE of five individual observations; (-) denotes percent decrease \& (+) denotes percent increase over control in the parenthesis.

$2 *$ Values are significant at $\mathrm{p}<0.05$.

Table 4. Changes in the hematological parameters (RBC, Hb, WBC, MCV, MCH) activity in Indian major carp, Labeo rohita treated with sublethal concentration of malathion $(0.34 \mathrm{ppm}, 30$ days).

\begin{tabular}{ccc}
\hline $\begin{array}{c}\text { Biochemical parameters } \\
\text { (mg/g wet tissue) }\end{array}$ & Control & Malathion treated fish \\
\hline Protein & & \\
Gill & $2.64 \pm 0.30$ & $0.76 \pm 0.11^{\star}(-71.21)$ \\
Liver & $3.23 \pm 0.08$ & $1.18 \pm 0.04^{\star}(-63.47)$ \\
Kidney & $2.14 \pm 0.15$ & $0.62 \pm 0.13^{\star}(-71.03)$ \\
Muscle & $1.34 \pm 0.10$ & $0.52 \pm 0.09^{\star}(-61.19)$ \\
Carbohydrate & & \\
Gill & $20.8 \pm 0.13$ & $7.90 \pm 0.18^{\star}(-60.66)$ \\
Liver & $17.75 \pm 0.18$ & $6.39 \pm 0.15^{\star}(-64.0)$ \\
Kidney & $19.0 \pm 0.12$ & $5.34 \pm 0.15^{\star}(-71.89)$ \\
Muscle & $8.40 \pm 0.09$ & $2.02 \pm 0.18^{\star}(-75.95)$ \\
Lipid & & \\
Gill & $27.4 \pm 0.09$ & $8.10 \pm 0.13^{\star}(-70.44)$ \\
Liver & $22.6 \pm 0.08$ & $9.1 \pm 0.19^{\star}(-59.73)$ \\
Kidney & $31.2 \pm 0.14$ & $4.2 \pm 0.14^{\star}(-86.54)$ \\
Muscle & $28.10 \pm 0.16$ & $3.41 \pm 0.15^{\star}(-87.86)$
\end{tabular}

\footnotetext{
${ }^{1}$ Values are means \pm SE of five individual observations; (-) denotes percent decrease \& (+) denotes percent increase over control in the parenthesis.

2 *Values are significant at $\mathrm{p}<0.05$.
} 


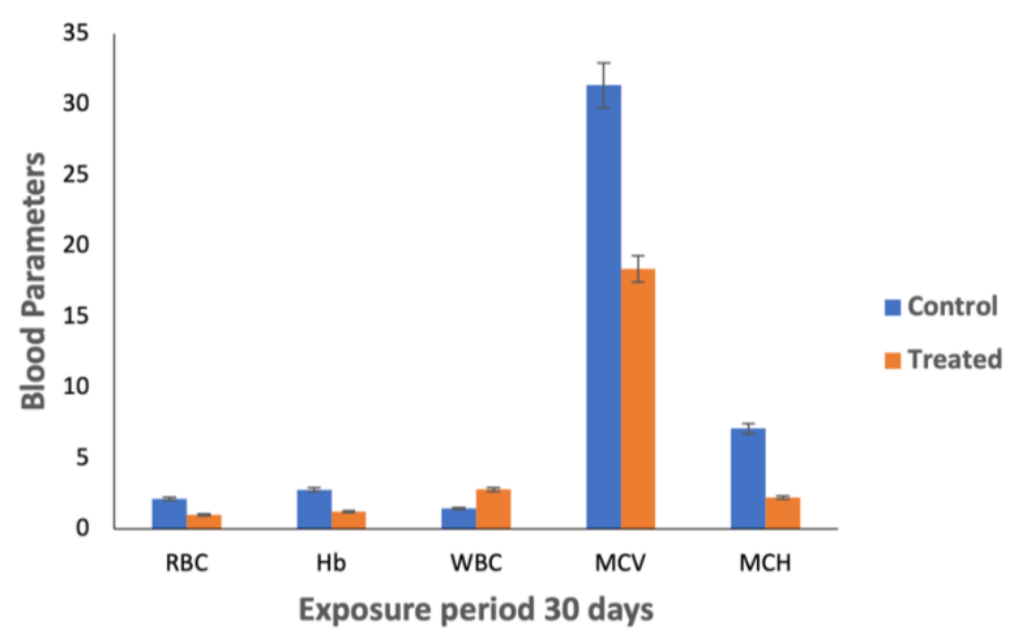

Figure 5. Hematological changes in control and malathion treated fish (0.34 ppm; 30 days). The bar represents SE of the mean. Comparison of means (control and treated fish) was done by Student's t-test.

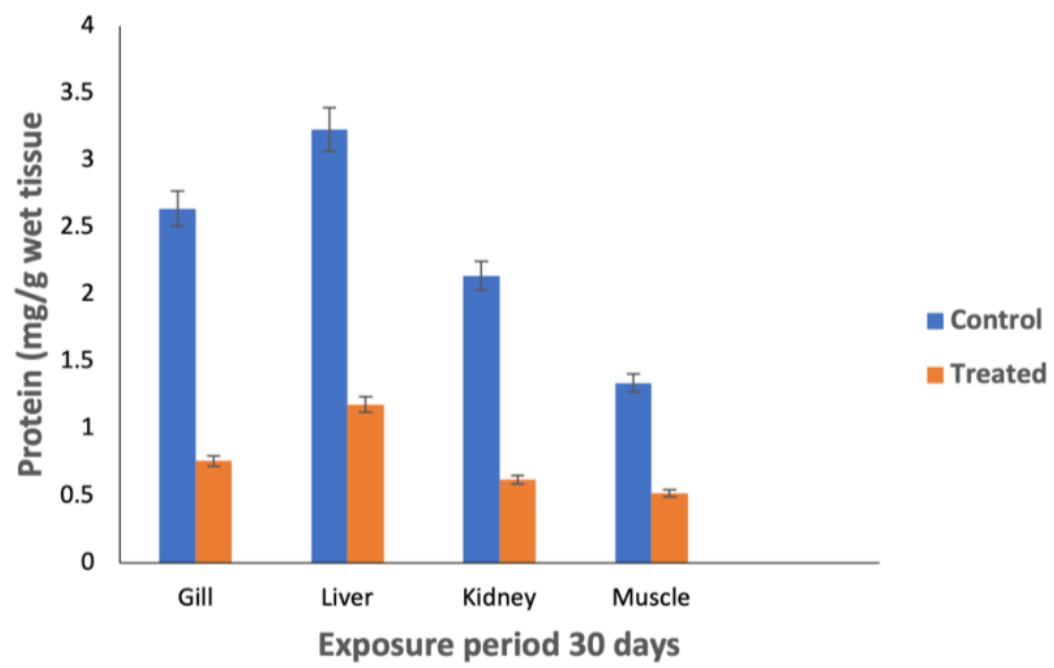

Figure 6. Changes in Protein metabolism of control and malathion treated fish ( 0.34 ppm; 30 days). The bar represents SE of the mean. Comparison of means (control and treated fish) was done by Student's t-test.

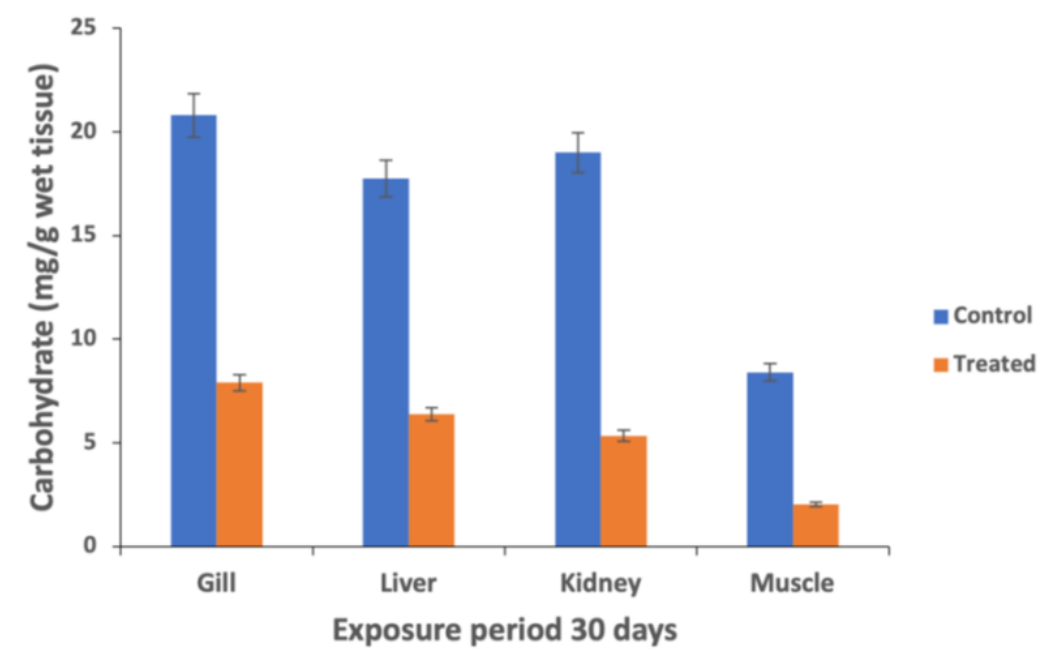

Figure 7. Changes in Carbohydrate metabolism of control and malathion treated fish (0.34 ppm; 30 days). The bar represents SE of the mean. Comparison of means (control and treated fish) was done by Student's t-test. 


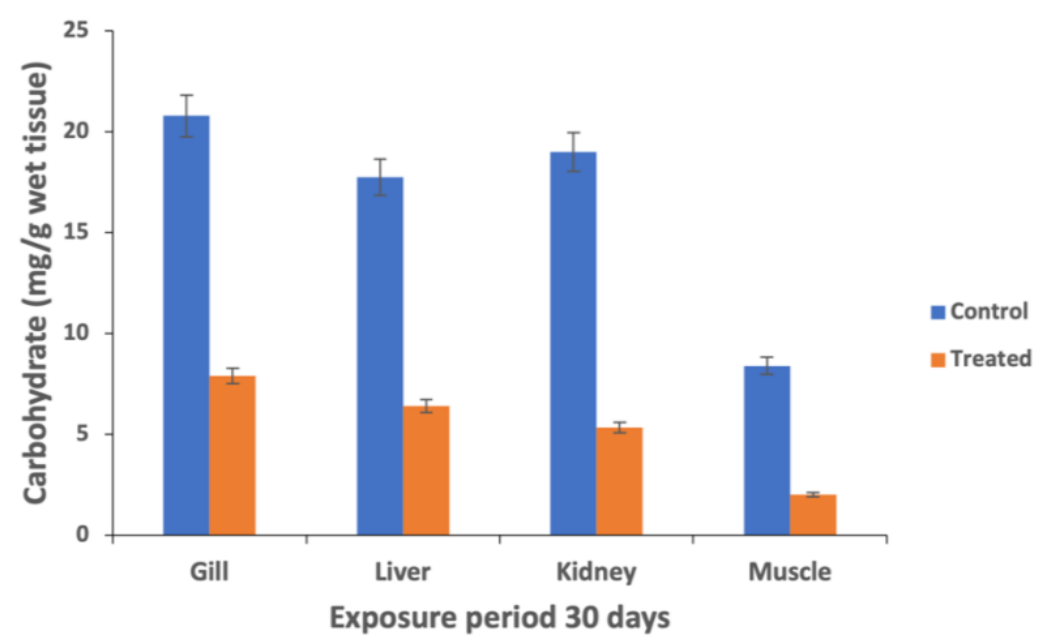

Figure 8. Changes in Lipid metabolism of control and malathion treated fish ( $0.34 \mathrm{ppm} ; 30$ days). The bar represents SE of the mean. Comparison of means (control and treated fish) was done by Student's t-test.

\section{Discussion}

To ensure the sustainability of aquatic life from inadvertent exposure to contaminants and prevent human health effects from the consumption of contaminated fish, the evaluation of pesticides' risk to non-target organisms like fish is imperative [21]. The pesticide exposed fishes exhibited a reduction in hematological values indicated anemia which may be due to erythropoiesis, haemosynthesis, and osmoregulatory dysfunction or due to an increase in the rate of erythrocyte destruction in hematopoietic organs $[22,23]$.

In the present study, during acute and sublethal treatment, the significant decrease $(\mathrm{p}<0.05)$ in $\mathrm{RBC}$ count might have resulted from severe anemic state or haemolysing power of toxicant (malathion), particularly on the red cell membrane. Similarly, the significant decrease $(\mathrm{p}<0.05)$ in the hemoglobin content in the present study may be due to the rapid oxidation of hemoglobin to methemoglobin or the release of $\mathrm{O}_{2}$ radicals brought about by the toxic stress of malathion. It is recognized that xenobiotics are capable of undergoing redox cycling can exert toxic effects by the generation of oxygen free radicals. A quick decrease in hemoglobin content in response to paraquat toxicity was observed in Cyprinus carpio by Matkovics et al. [24] and the authors suggested that it might presumably through methemoglobin formation and direct response of $\mathrm{O}_{2-}$ radicals.

Leucocytosis manifests in the form of leucocytosis with heterophilia and lymphopenia which are characteristics leucocytic response in animals exhibiting stress [1]. In the present study, the significant increase $(p<0.05)$ in WBC count may be due to immunological reactions to produce antibodies to cope up with stress-induced by malathion which indicates hypersensitivity of leucocytes to malathion. The present result can be correlated with an increase in antibody production which helps in survival and recovery of the fish exposed to lindane and malathion [25].

The results also revealed that after malathion exposure, other hematological indices including $\mathrm{MCV}$ and $\mathrm{MCH}$ experienced a considerable decrease $(\mathrm{p}<0.05)$. The alterations in $\mathrm{MCV}$ and $\mathrm{MCH}$ were ascribed to hemolysis and impairment in hemoglobin synthesis [26,27]. The $\mathrm{MCH}$ is a good indicator of red blood cell swelling [28,29]. Specifically, Oluah and Omerebel [30] found a decrease in $\mathrm{MCV}$, and $\mathrm{MCH}$ after exposure of Clarias gariepinus to lead. Similar findings were recorded by Ololade and Ogini [31] after the exposure of Clarias gariepinus to Zinc.

Under conditions of stress, many organisms will mobilize proteins as an energy source for the oxidation of amino acids. In the present study, the significant decrease $(p<0.05)$ of protein content may be due to stress-mediated immobilization of these compounds to fulfill an increased element for energy by the fish to cope with environmental conditions exposed by the toxicant [22]. The augmented proteolysis and possible utilization of their product for metabolic purposes may be the reason for the depletion in total protein content as reported by Ravinder et al [32]. On the other hand, Neff [33] has opined that a decline in protein content may be related to impaired food intake, increased energy cost of homeostasis, tissue repair, and detoxification mechanism during stress.

The results of the present study showed that the carbohydrate metabolism in gill, liver, kidney, and muscle is disrupted on exposure to malathion. Changes in carbohydrates have been suggested as a useful general indicator of stress in teleost. In the case of stress, carbohydrates are the first and immediate energy source to be utilized to a greater extent [34]. Hence, a reduction of total carbohydrates content in various tissues occurred on exposure to any kind of pollutant or toxicants. Carbohydrate reserves are depleted to meet energy requirements by all tissues under stressful conditions [35]. The carbohydrate content in the tissues in the present study significantly decreased $(\mathrm{p}<0.05)$ which may be due to rapid 
utilization to meet the enhanced energy demands through glycolysis or hexose monophosphate pathway. Another reason for the decrease in glycogen content may be the inhibition of the enzyme glycogen synthetase. A decrease in tissue glycogen was observed in Labeo rohita on exposure to malathion and nuvan [36]. A similar reduction in tissue glycogen was observed when Sarorherodo mossambicus was exposed to DDT, malathion, and mercury [37]. The findings of the present study are also in agreement with those of Bakhshwan et al [38].

Lipids support as energy reserves to meet the metabolic requirement for more energy to mitigate toxic stress [39]. In the present investigation, the observed significant diminution $(\mathrm{p}<0.05)$ of the lipid profile may be due to increased lipid metabolism during stress conditions. A similar result was reported by Kumar and Gautam [40] in Channa punctatus with nuvan. The decline in the lipid levels may be due to the inhibition of cholesterol biosynthesis in the liver or due to reduced absorption of dietary cholesterol. A decrease in the lipid content of the gill, liver, kidney, and muscle tissues exposed to malathion recommends that lipid might have been directed for energy production for other metabolic functions in which these products play a key role during toxicant stress condition.

\section{Conclusions}

The study shows that non-target organisms in aquatic ecosystems such as Labeo rohita may be at risk of toxic effects of acute and sublethal concentrations of malathion. The present study declares that malathion is a highly toxic pesticide to Labeo rohita and the presence of malathion even at very low concentrations may cause adverse effects on aquatic organisms. Consistent biomonitoring and sensitization of stakeholders on responsible pesticide use are therefore imperative to forestall adverse ecological effects in aquatic ecosystems. To evaluate the toxic effect of malathion and other pesticides, the studied parameters in the experiment could be used as potential biomarkers. Further, ecological risk indices for this pesticide should be developed to safeguard aquatic life within the ambits of the United Nations Sustainable Development Goal 14 (sustaining life below water).

\section{Acknowledgement}

The authors are thankful to the Department of Zoology, Kongunadu Arts and Science College, Coimbatore for providing necessary arrangements to carry out this research study.

\section{Ethical statement}

We declare that we do not need ethics approval to conduct the experimental work on major carp (Labeo rohita).

\section{Conflict of interest}

The authors declare that they have no conflict of interest.

\section{CRediT author statement}

JMS: Writing-Reviewing and Editing, Writing-original draft preparation, Data curation, and analysis; SB: Conceptualization, Methodology, and Supervision.

\section{ORCID}

Juginu M S: 0000-0003-3299-8533

\section{References}

[1] Ramesh M, Saravanan M. Haematological and biochemical responses in a freshwater fish cyprinus carpio exposed to chlorpyrifos. Int J Integ Biol 2008;3(1):80-83.

[2] Al-Otaibia AM, Al-Balawia HFA, Ahmada Z, Sulimana EM. Toxicity bioassay and sub-lethal effects of diazinon on blood profile and histology of liver, gills and kidney of catfish, Clarias gariepinus. Braz J Biol 2017;79:326-336. https://doi.org/10.1590/1519-6984.185408

[3] Bhatnagar MC, Bana AK, Tyagi M. Respiratory distress to clarias batrachus (Linn.) exposed to endosulfan-a histological approach. J Environ Biol 1992; 13(3): 227-231.

[4] Satheeshkumar P, Ananthan G, Senthil Kumar D, Jagadeesan L. Haematology and biochemical parameters of different feeding behaviour of teleost fishes from Vellar estuary, India. Comp Clin Pathol 2012;21(6)1187-1191.

https://doi.org/10.1007/s00580-011-1259-7 
[5] Cnaani A, Tinman S, Avidar Y, Ron M, Hulata G. Comparative study of biochemical parameters in response to stress in Oreochromis aureus, Oreochromis mossambicus and two strains of O. niloticus. Aquaculture Res 2004;35(15):1434-1440. https://doi.org/10.1111/j.1365-2109.2004.01167.x

[6] Satheeshkumar P, Senthilkumar D, Ananthan G, Soundarapandian P, Khan AB. Measurement of hematological and biochemical studies on wild marine carnivorous fishes from Vellar estuary, southeast coast of India. Comp Clin Pathol 2011;20(2):127-134. https://doi.org/10.1007/s00580-010-0966-9

[7] Syeda Hina Kauser, Rafath Yasmeen. Biochemical alterations effecting carbohydrate metabolism of Cyprinus carpio (common carp) on exposure to botanical pesticide - anosom.Trends in Fisheries Research 2019; 8(2).

[8] Sudhasaravanan R, Binukumari S. A study on the effect of insecticide malathion on the hematology of the freshwater fish“Catla catla”. Int J Pharm Sci 2015;3(6), 1215-1217.

[9] American Public Health Association (APHA). Standard methods for the examination of water and wastewater. 20th ed. American Public Health Association; 1998, Washington DC; USA. https://doi.org/10.5860/choice.37-2792

[10] Finney DJ. Statistical methods in biological assay. 3rd ed. Charles Griffin \& company Press;1978, 508. https://doi.org/10.1002/bimj.4710210714

[11] Sprague JB. Measurement of pollution toxicity to fish III. Sublethal effects and "safe" concentration. Water Research 1971;5(6):245-266. https://doi.org/10.1016/0043-1354(71)90171-0

[12] Rusia V, Sood SK. Routine haematological tests in medical laboratory technology. Mukerjee, KL, ed. Tata McGraw Hill Publishing Company Limited 1992;252-258.

[13] Drabkin DL. Spectrophotometric studies XIV- The crystallographic and optical properties of the haemoglobin of man in comparison with those of other species. J Biol Chem 1946;164(2):703-723.

[14] Dacie JV, Lewis SM. Practical haematology. 6th ed. ELBS and Churchill; 1984, Livingston.

[15] Lowry OH, Rosebrough NJ, Farr AL, Randall RJ. Protein measurement with the folin phenol reagent. J Biol Chem 1951;193:265. https://doi.org/10.1016/S0021-9258(19)52451-6

[16] Seifter S, Dayton S, Novic B, Muntwyler E. The estimation of glycogen with the anthrone reagent. Arch Biochem 1950;25: 191-200.

[17] Barnes H, Blackstock J. Estimation of lipids in marine animals and tissues: detailed investigation of the sulphosphovanillin method for ' total' lipids. J Exp Mar Biol Ecol 1973;12(1):103-118. https://doi.org/10.1016/00220981(73)90040-3

[18] Brugs WA, McCormick JH, Neiheisel TW, Spear RL, Stephan CE, Stokes G. Effect of pollution on freshwater fish. Journal (Water Poll Cont Fed) 1977;49(6):1425-1493.

[19] El-Sayed YS, Saad TT, El-Bahr SM. Acute intoxication of deltamethrin in monosex Nile tilapia, Oreochromis niloticus with special reference to the clinical, biochemical and hematological effects. Env Toxicol Pharm 2007;24(3):212-217. https://doi.org/10.1016/j.etap.2007.05.006

[20] Velíšek, J, Jurčíková, J, Dobšíková, R, Svobodova, Z, Piačková, V, Machova J, et al. Effects of deltamethrin on rainbow trout (Oncorhynchus mykiss). Env Toxicol Pharm 2007;23(3):297-301. https://doi.org/10.1016/j.etap.2006.11.006

[21] Oladokun EI, Sogbanmu TO, Anikwe JC. Sublethal concentrations of dichlorvos and paraquat induce genotoxic and histological effects in the Clarias gariepinus. Env Anal Health Toxicol 2020;35(3). https://doi.org/10.5620/eaht.2020013

[22] Jenkins F, Smith J, Rajanna B, Shameem U, Umadevi K, Sandhya V, et al. Effect of sublethal concentration of endosulfan on hematological and serum biochemical parameters in the carp cyprinus carpio. Bull Environ Contam Toxicol 2003; 70(5): 0993-0997. https://doi.org/10.1007/s00128-003-0080-7

[23] Seth N, Saxena KK. Hematological responses in a freshwater fish, Channa punctatus due to fenvalerate. Bull Environ Contam Toxicol 2003; 71(6): 1192-1199. https://doi.org/10.1007/s00128-003-8732-1

[24] Matkovics B, Witas H, Gabrielak T, Szabo L. Paraquat as an agent affecting antioxidant enzymes of common carp erythrocytes. Comp Biochem Physiol 1987;87(1):217-219. https://doi.org/10.1016/0742-8413(87)90206-4

[25] Joshi P, Harish D, Bose M. Effect of lindane and malathion exposure to certain blood parameters in a freshwater teleost fish Clarias batrachus. Poll Res 2002;21(1):55-57. 
[26] Marei M, Haggag A, El-Badawy A. Physiological and biochemical responses of the common carp, Cyprinus carpio, to an organophosphorous insecticide Profenofos. Egypt J Zool 1998;13:279-302.

[27] Shah SL. Haematological parameters in tench Tinca tinca after short term exposure to lead. J Appl Toxicol: an international Journal 2006;26(3):223-228. https://doi.org/10.1002/jat.1129

[28] Wepener V, Van Vuren JHJ, Du Preez HH. The effect of hexavalent chromium at different $\mathrm{pH}$ values on the haematology of Tilapia sparmani (Cichlidae). Comp Biochem Physiol 1992;101(2):375-381. https://doi.org/10.1016/07428413(92)90290-N

[29] Bhagwant S, Bhikajee M. Induction of hypochromic macrocytic anaemia in Oreochromis hybrid (cichlidae) exposed to $100 \mathrm{mg} / \mathrm{L}$ (sublethal dose) of aluminium. University of Mauritius Research Journal 2000;5:9-20.

[30] Stanley ON, Omerebele UA. Changes in haematological parameters of Clarias gariepinus exposed to lead poisoning. J fisher Inter 2010;5(4):72-76. https://doi.org/10.3923/jfish.2010.72.76

[31] Ololade IA, Oginni O. Toxic stress and hematological effects of nickel on African catfish, Clarias gariepinus, Fingerlings. Journal of environmental chemistry and Ecotoxicology 2010;2(2): 014- 019. https://doi.org/10.5897/JECE.9000060

[32] Ravinder V, Suryanarayana N, Narayana G. Decis induced biochemical alterations in a freshwater catfish, Clarias batrachus. Indian J Comp Animal Physiol 1988;6:5-12.

[33] Neff JM. "Use of biochemical measurements to detect pollutant-mediated damage to fish", in aquatic toxicology and hazard assessment: Seventh symposium. ASTM International 1985;155-181. https://doi.org/10.1520/STP36266S

[34] Tasneem S, Yasmeen R. Biochemical changes in carbohydrate metabolism of the fish -Cyprinus carpio during sub-lethal exposure to biopesticide - Derisom. Iran J Fish Sci 2017;19(2):961-973. https://doi.org/10.22092/IJFS.2018.116876

[35] Arasta T, Bais VS, Thakur P. Effect of nuvan on some biochemical parameters of Indian cat fish Mystus vittatus. J Env Biol 1996;17(2):167-169.

[36] Anuradha G. Impact of organophosphate pesticides on Labeo rohita diss Ph. D Thesis. Osmania University;1993 (India).

[37] Ramalingam K. Toxic effects of DDT, malathion and mercury on the tissue of carbohydrate metabolism of Sarotherodon mossambicus (Peters). Proceedings: Animal Sciences 1988;97(5):443-448. https://doi.org/10.1007/BF03179951

[38] Bakhshwan S, Hamed H, Marzouk M, Hanna M. Some investigations on the clinical and biochemical alterations associated with diazinon toxicity in Clarias gariepinus. Egypt J Aq Biol Fish 2009;13(2):173-197. https://doi.org/10.21608/ejabf.2009.2039

[39] Nagaraju B, Hagos Z, Babu KR, Krishnan G, Chaitanya K, Teka Z, et al. Effect of an insecticide chlorantraniliprole on biochemical characteristics of snakehead fish, Channa punctatus (Bloch, 1793). Inn J Agri Sci 2018;6(1): 2321-4832.

[40] Kumar S, Gautam RK. Study of biochemical toxicity of nuvan in Channa punctatus (Bloch.). Adv Res Agri Vet Sci 2014;1(1):31-34.

[41] Akter R, Pervin MA, Jahan H, Rakhi SF, Reza AM, Hossain Z. Toxic effects of an organophosphate pesticide, envoy 50 SC on the histopathological, hematological, and brain acetylcholinesterase activities in stinging catfish, heteropneustes fossilis. The Journal of Basic and Applied Zoology 2020; 81(1)1-14. https://doi.org/10.1186/s41936-020-00184-W

[42] Kori-Siakpere O, Ake JEG, Idoge E. Haematological characteristics of the African snakehead, Parachacnna obscura. Afr J Biotech 2005;4(6):527-530.

[43] Tasneem S, Yasmeen R. Biochemical changes in carbohydrate metabolism of the fish-Cyprinus carpio during sub-lethal exposure to biopesticide-Derisom. Iran J Fish Sci 2020; 19(2): 961-973. https://doi.org/10.22092/IJFS.2018.116876

[44] Bhoi SS, Patole SS. Biochemical changes of freshwater fish, Channa marulius (Ham Buch) exposed to 3/4th sub lethal concentration of Cypermethrin and Fenvalerate. Int J of Life Sciences 2019; A13:14-18. 